\title{
Identification, Cloning, and Characterization of L-Phenylserine Dehydrogenase from Pseudomonas syringae NK-15
}

\author{
Sakuko Ueshima, ${ }^{1}$ Hisashi Muramatsu, ${ }^{2}$ Takanori Nakajima, ${ }^{3}$ Hiroaki Yamamoto, ${ }^{4}$ \\ Shin-ichiro Kato, ${ }^{5}$ Haruo Misono, ${ }^{2}$ and Shinji Nagata ${ }^{2}$ \\ ${ }^{1}$ The United Graduate School of Agricultural Science, Ehime University, 3-5-7 Tarumi, Matsuyama 790-8566, Japan \\ ${ }^{2}$ Faculty of Agriculture, Kochi University, B200 Monobe, Nankoku, Kochi 783-8502, Japan \\ ${ }^{3}$ Corporate Research Center, R\&D Management, Daicel Chemical Industries, Ltd., 1239 Shinzaike, Aboshi-ku, Himeji 671-1283, Japan \\ ${ }^{4}$ Himeji Research Center, Daicel Chemical Industries, Ltd., 1239 Shinzaike, Aboshi-ku, Himeji 671-1283, Japan \\ ${ }^{5}$ Science Research Center, Kochi University, B200 Monobe, Nankoku, Kochi 783-8502, Japan \\ Correspondence should be addressed to Hisashi Muramatsu, hmura@kochi-u.ac.jp
}

Received 29 July 2009; Revised 28 October 2009; Accepted 29 November 2009

Academic Editor: Paul Engel

Copyright ( $) 2010$ Sakuko Ueshima et al. This is an open access article distributed under the Creative Commons Attribution License, which permits unrestricted use, distribution, and reproduction in any medium, provided the original work is properly cited.

\begin{abstract}
The gene encoding D-phenylserine dehydrogenase from Pseudomonas syringae NK-15 was identified, and a 9,246-bp nucleotide sequence containing the gene was sequenced. Six ORFs were confirmed in the sequenced region, four of which were predicted to form an operon. A homology search of each ORF predicted that orf3 encoded L-phenylserine dehydrogenase. Hence, orf3 was cloned and overexpressed in Escherichia coli cells and recombinant ORF3 was purified to homogeneity and characterized. The purified ORF3 enzyme showed L-phenylserine dehydrogenase activity. The enzymological properties and primary structure of L-phenylserine dehydrogenase (ORF3) were quite different from those of D-phenylserine dehydrogenase previously reported. $\mathrm{L}$-Phenylserine dehydrogenase catalyzed the $\mathrm{NAD}^{+}$-dependent oxidation of the $\beta$-hydroxyl group of $\mathrm{L}-\beta$-phenylserine. $\mathrm{L}$ Phenylserine and L-threo-(2-thienyl)serine were good substrates for L-phenylserine dehydrogenase. The genes encoding Lphenylserine dehydrogenase and D-phenylserine dehydrogenase, which is induced by phenylserine, are located in a single operon. The reaction products of both enzymatic reactions were 2 -aminoacetophenone and $\mathrm{CO}_{2}$.
\end{abstract}

\section{Introduction}

3-Hydroxy-2-amino acids are components of many bioactive molecules, such as antibiotics and immunosuppressants [1-9] and a drug for Parkinson's disease therapy [10]. Therefore, enzymatic synthesis of 3-hydroxy-2-amino acids with $\mathrm{D}^{-}$and $\mathrm{L}$-threonine aldolases has been performed extensively $[1,2,4-9]$. $\beta$-Phenylserine (2-amino-3-hydroxy3 -phenylpropanoic acid), which exists as four stereoisomers, is one of the physiologically important 3-hydroxy-2-amino acids [11-13]. However, until recently, little was known about phenylserine biosynthetic and degradation pathways. To elucidate metabolic processes involving phenylserine, we have attempted to obtain enzymes physiologically acting on phenylserine. Previously, we reported the molecular characteristics of inducible pyridoxal 5'-phosphate (PLP)-dependent phenylserine aldolase [EC 4.1.2.26] [14],
PLP-dependent phenylserine dehydratase [EC 4.2.1.-] [15], and inducible $\mathrm{NADP}^{+}$-dependent $\mathrm{D}$-phenylserine dehydrogenase [EC 1.1.1.-] (Scheme 1) [16]. During the identification of the gene encoding D-phenylserine dehydrogenase, we found the gene encoding L-phenylserine dehydrogenase [EC 1.1.1.-] in the same operon. In this paper, we report the identification and cloning of the genes encoding D-phenylserine dehydrogenase and L-phenylserine dehydrogenase. Moreover, the enzymological properties of L-phenylserine dehydrogenase (Scheme 1) overexpressed in Escherichia coli are described.

\section{Materials and Methods}

2.1. Materials. D-threo- $\beta$-Phenylserine was a gift from Mr. Teruyuki Nikaido, Daicel Chemical Industries (Hyogo, Japan). Polypepton was from Nihon Pharmaceutical (Tokyo, 
Japan). $\mathrm{NAD}^{+}, \mathrm{NADP}^{+}$, yeast extract, and molecular-weight marker-proteins for gel filtration were from Oriental Yeast (Tokyo, Japan). Restriction enzymes and kits for genetic manipulation were from Takara Shuzo (Kyoto, Japan), Toyobo (Osaka, Japan), and New England Biolabs (Beverly, MA). All other reagents were of analytical grade from Sigma (St. Louis, MO), Nacalai Tesque (Kyoto, Japan), and Wako Pure Chemical Industries (Osaka, Japan).

2.2. Cultivation. Pseudomonas syringae NK-15 was cultivated at $30^{\circ} \mathrm{C}$ in a medium containing $0.5 \%$ DL-threo$\beta$-phenylserine, $1.5 \%$ polypepton, $0.2 \% \quad \mathrm{~K}_{2} \mathrm{HPO}_{4}, 0.2 \%$ $\mathrm{KH}_{2} \mathrm{PO}_{4}, 0.2 \% \mathrm{NaCl}, 0.01 \% \mathrm{MgSO}_{4} \cdot 7 \mathrm{H}_{2} \mathrm{O}$, and $0.01 \%$ yeast extract ( $\mathrm{pH}$ 7.2) with reciprocal shaking [16].

2.3. Determination of Internal Amino Acid Sequence. Purified D-phenylserine dehydrogenase, prepared as previously described [16], was lyophilized and suspended in $8 \mathrm{M}$ urea. After incubation for 1 hour at $37^{\circ} \mathrm{C}$, the enzyme was digested with lysyl endopeptidase for 15 hours at $37^{\circ} \mathrm{C}$. The resultant peptides were separated on a Shimadzu HPLC system equipped with a YMC-Pack C4 column $(6 \times 150 \mathrm{~mm}$, YMC Co., Kyoto, Japan) using a solvent system of $0.1 \%$ trifluoroacetic acid (solvent A) and acetonitrile containing $0.07 \%$ trifluoroacetic acid (solvent B). A 90-min linear gradient from 5 to $50 \%$ solvent $\mathrm{B}$ was used to elute peptides at a flow rate of $1.0 \mathrm{ml} / \mathrm{min}$. The absorbance at $210 \mathrm{~nm}$ of the effluent was continuously monitored. The internal amino acid sequence of D-phenylserine dehydrogenase was determined using an automated protein sequencer (Perkin Elmer, Wellesley, MA).

2.4. Identification of the Gene Encoding D-Phenylserine Dehydrogenase and Gene Organization. Based on the N-terminal amino acid sequence of $\mathrm{D}$-phenylserine dehydrogenase, determined as described previously [16], and the internal amino acid sequence of the enzyme determined in this work, inverse PCR was performed to identify the gene encoding D-phenylserine dehydrogenase. PCR products were sequenced with an Applied Biosystems 373A DNA sequencer and a DNA sequencing kit (ABI PRISM Dye Terminator Cycle Sequencing Ready Reaction Kit). Inverse PCR was also used to determine the nucleotide sequence of the regions upstream and downstream of the $\mathrm{D}$-phenylserine dehydrogenase gene.

2.5. Cloning and Expression of the Gene Encoding DPhenylserine Dehydrogenase and the Orf3 Gene in Escherichia coli. Chromosomal DNA was prepared from P. syringae NK-15 by the method of Saito and Miura [17]. A DNA fragment containing the gene encoding $\mathrm{D}$-phenylserine dehydrogenase was amplified by PCR with Ex Taq DNA polymerase (Takara Shuzo, Kyoto, Japan) using a sense primer containing an EcoRI site (5' - GCGGAATTCGAATCCGCCAACCCACGCCAAGGAATAACGCA - $3^{\prime}$ ) and an antisense primer containing a PstI site (5' - GCGAAGCTTCTGCAGCAAGCAGCGCTCACGTCGAAGCGCACA- $3^{\prime}$ ).
The amplified DNA fragment was ligated into the EcoRIPstI site of pUC18. The resultant plasmid, pUPsDH, was introduced into E. coli JM109 to provide recombinant Dphenylserine dehydrogenase. E. coli JM109 carrying pUPsDH was cultivated in LB medium containing $50 \mu \mathrm{g} / \mathrm{ml}$ ampicillin and $0.1 \mathrm{mM}$ isopropyl- $\beta$-D-thiogalactopyranoside (IPTG) at $37^{\circ} \mathrm{C}$ for 20 hours. A DNA fragment containing the orf 3 gene was amplified using a sense primer containing an EcoRI site and the ATG start codon (5'-GGGAATTCAGGAAACAGACCATGAGTTTTCCGGTTTGTCTCGTCA$\left.3^{\prime}\right)$ and an antisense primer containing a HindIII site $\left(5^{\prime}\right.$ GGAAGCTTATGTGTTGAGCAGCAGCCCGxTTCTCGATCG $3^{\prime}$ ). The amplified DNA fragment was ligated into the EcoRI-HindIII site of pSE420D (Daicel Chemical Industries, Osaka, Japan) [18]. The resultant plasmid, pSORF3, was deposited in the International Patent Organism Depositary, National Institute of Advanced Industrial Science and Technology (Ibaraki, Japan) under accession number FERM-P20287. To obtain recombinant ORF3, E. coli JM109 carrying pSORF3 was cultivated in LB medium containing $50 \mu \mathrm{g} / \mathrm{ml}$ ampicillin and $0.1 \mathrm{mM} \mathrm{IPTG}$ at $37^{\circ} \mathrm{C}$ for 16 hours.

2.6. Purification of the orf3 Gene Product. The standard buffer used throughout purification was $10 \mathrm{mM}$ potassium phosphate buffer ( $\mathrm{pH} 8.0)$, and all operations were done at $4^{\circ} \mathrm{C}$. Cultured E. coli cells expressing ORF3 were harvested by centrifugation, resuspended in $0.1 \mathrm{M}$ potassium phosphate buffer ( $\mathrm{pH}$ 8.0) containing $0.02 \%$ 2-mercaptoethanol (2$\mathrm{ME}$ ) and $2 \mathrm{mM}$ phenylmethylsulfonyl fluoride (PMSF), and disrupted using a Micro Smash MS-100 (TOMY, Tokyo, Japan). After centrifugation, the supernatant was fractionated by ammonium sulfate precipitation ( $0-50 \%$ saturation). The enzyme-containing fraction was resuspended in $0.1 \mathrm{M}$ potassium phosphate buffer ( $\mathrm{pH} 8.0$ ) containing $0.02 \% 2$ $\mathrm{ME}$ and $2 \mathrm{mM}$ PMSF, and dialyzed against the same buffer. The enzyme fraction was applied to a Q-Sepharose FF column (Pharmacia, Columbus, $\mathrm{OH}$ ) equilibrated with the standard buffer containing 0.01\% 2-ME. The enzyme was eluted with a linear gradient of $0-0.5 \mathrm{M} \mathrm{NaCl}$ in the same buffer. The enzyme fractions were collected, concentrated, dialyzed against the standard buffer containing $0.01 \% 2$ $\mathrm{ME}$ and $20 \%$ saturated ammonium sulfate, and centrifuged. The supernatant was applied to a Phenyl superose HP 26/10 column (Pharmacia, Columbus, $\mathrm{OH}$ ) equilibrated with the standard buffer containing $0.01 \% 2-\mathrm{ME}$ and $30 \%$ saturated ammonium sulfate. The enzyme was eluted with a linear gradient of $20-0 \%$ saturated ammonium sulfate in the buffer. The enzyme fractions were collected, concentrated and dialyzed against the standard buffer containing $0.01 \% 2-$ $\mathrm{ME}$. The final preparation of the enzyme was stored at $-80^{\circ} \mathrm{C}$ until use.

2.7. Enzyme Assay. L-Phenylserine dehydrogenase activity was assayed by monitoring the increase in absorbance at $340 \mathrm{~nm}$ due to the production of $\mathrm{NADH}$ at $30^{\circ} \mathrm{C}$ in a $1-\mathrm{ml}$ reaction mixture containing $20 \mathrm{mM}$ DL-threo- $\beta$ phenylserine and $2.5 \mathrm{mM} \mathrm{NAD}^{+}$in $0.2 \mathrm{M}$ Glycine-KCl-KOH buffer ( $\mathrm{pH}$ 10.5). D-Phenylserine dehydrogenase activity was determined as previously described [16]. 


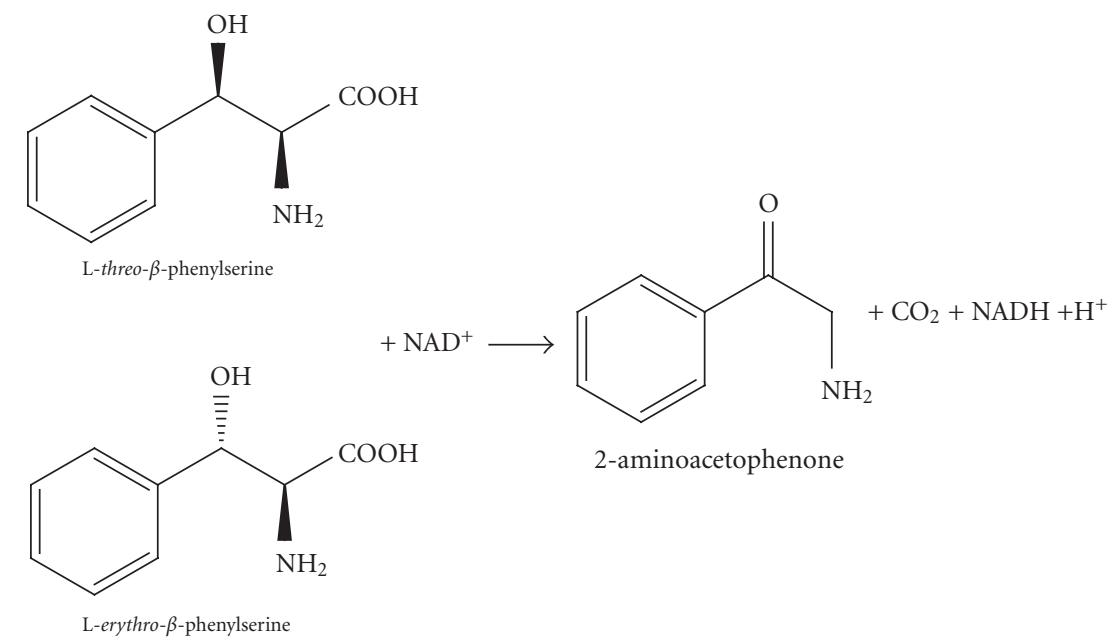

(a)



(b)

Scheme 1: Reactions catalyzed by L-phenylserine dehydrogenase (a) and D-phenylserine dehydrogenase (b).

2.8. Thin Layer Chromatography (TLC) Analysis. A reaction solution containing $40 \mathrm{mM}$ DL-threo- $\beta$-phenylserine, $4.8 \mathrm{mM} \mathrm{NAD}{ }^{+}$, and $0.3 \mathrm{mg} / \mathrm{ml}$ purified ORF3 in $0.1 \mathrm{M}$ Glycine-KCl-KOH buffer ( $\mathrm{pH}$ 10.5) was incubated overnight at $30^{\circ} \mathrm{C}$. The reaction solution, DL-threo- $\beta$-phenylserine, and 2-aminoacetophenone were applied to a TLC plate, Kieselgel $60 \mathrm{~F}_{254}$ (Merck, Darmstadt, Germany). The chromatogram was developed using $n$-butanol-acetic acid-water (4:1:1, by vol.). The spots of DL-threo-phenylserine and 2aminoacetophenone were detected by spraying the TLC plate with $1.5 \%$ ninhydrin solution in acetone-ethanol $(7: 3$, by vol.) and incubating at $65^{\circ} \mathrm{C}$ until color developed.

2.9. Analytical Methods for Enzyme. Protein concentration was determined using a Protein assay kit (Bio-Rad, Hercules, CA) with bovine serum albumin as standard. The molecular mass of the subunit of L-phenylserine dehydrogenase was examined by SDS-PAGE using Protein Markers for SDSPAGE (Nacalai Tesque, Kyoto, Japan). The molecular mass of native L-phenylserine dehydrogenase was estimated by HPLC on a TSK-GEL G3000SW column $(0.75 \times 60 \mathrm{~cm})$ operating at room temperature. The column was eluted with $0.1 \mathrm{M}$ potassium phosphate buffer ( $\mathrm{pH} 7.0$ ) containing $0.2 \mathrm{M} \mathrm{NaCl}$ at a flow rate of $0.7 \mathrm{ml} / \mathrm{min}$. Amino acid sequences were obtained from PubMed at NCBI (http://www.ncbi.nlm.nih.gov/). A homology search was performed using the BLAST program [19] at GenomeNet (http://www.genome.ad.jp/). Multiple alignments were obtained with the ClustalW program [20] at GenomeNet (http://www.genome.ad.jp/).

2.10. Nucleotide Sequence Accession Number. The nucleotide sequence data have been deposited in the DDBJ/EMBL/ GenBank nucleotide sequence databases under accession number AB499092.

\section{Results}

3.1. Identification of a Gene Encoding D-Phenylserine Dehydrogenase. Purified D-phenylserine dehydrogenase was obtained as previously described [16]. The enzyme was digested with lysyl endopeptidase, and the peptide products were purified by reversed-phase HPLC. The amino acid sequences of only two internal peptides could be determined (Figure 1). Based on the $\mathrm{N}$-terminal amino-acid sequence and the internal amino acid sequences determined, an $897-$ bp nucleotide sequence was identified as the gene encoding D-phenylserine dehydrogenase (Figure 1). A crude extract of E. coli JM109 transformed with the pUPsDH expression vector containing the gene showed D-phenylserine dehydrogenase activity $(33 \mathrm{U} / \mathrm{mg})$, while that of wild-type E. coli JM109 was inactive.

3.2. Gene Organization of Regions Upstream and Downstream of the D-Phenylserine Dehydrogenase Gene. To determine the nucleotide sequence of upstream and downstream regions 
ATGGAATCGAATCATCCCCCGCGAGTCGGGTTTTGCGGCATCGGTCGCATGGGCGAACCG

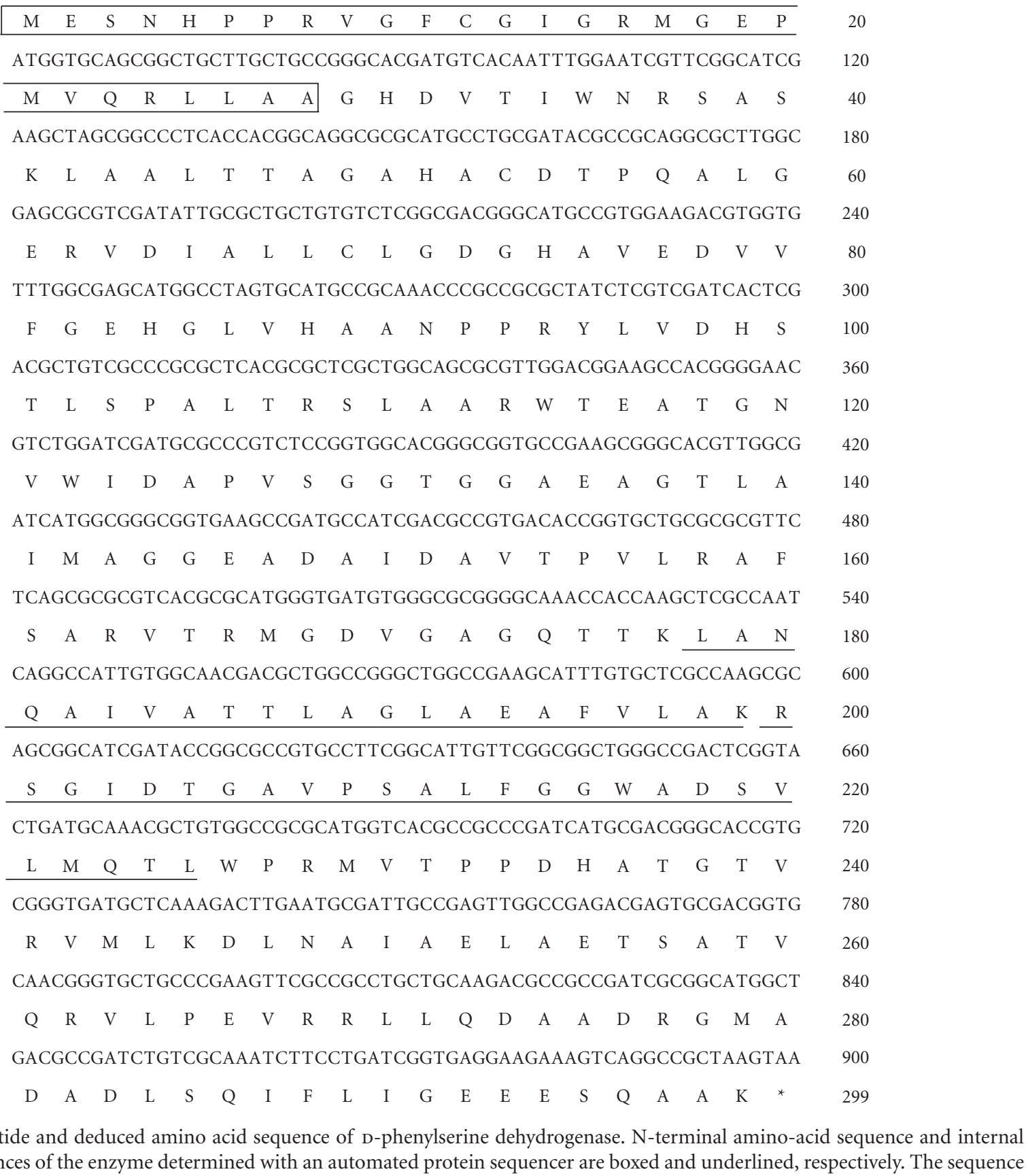

FIGURE 1: Nucleotide and deduced amino acid sequence of D-phenylserine dehydrogenase. N-terminal amino-acid sequence and internal data are deposited in the DDBJ/EMBL/GenBank database under the accession number AB499092.

of the gene encoding D-phenylserine dehydrogenase, inverse PCR was carried out. As a result, a 9,246-bp nucleotide sequence containing at least six open reading frames (ORFs) was determined (Figure 2). The transcriptional directions of orf1 and orf6 are opposite to those of the four other ORFs. Postulated promoter and terminator sequences are located immediately upstream of orf 2 and downstream of D-phenylserine dehydrogenase encoding orf5, respectively. These observations suggest that orf2, orf 3 , orf4, and orf5 may form an operon. orf1 encodes a protein of 320 amino acids that is similar to amino acid sequences of putative LysR-type transcriptional regulators. Thus, orf 1 probably plays a role in the regulation of transcription of the operon. orf 2 encodes a protein of 436 amino acids that shows sequence similarity to putative major facilitator superfamily (MFS) transporters. orf4 encodes a protein of 579 amino acids that is similar to amino acid sequences of putative dihydroxy acid dehydratases (ilvD). The $i l v D$ gene has previously been identified in the ilv operon involved in branched-chain amino acids 


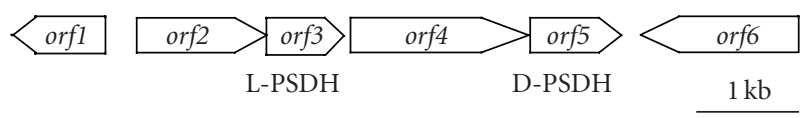

FIGURE 2: Genetic map around the D-phenylserine dehydrogenase gene. orf1: putative transcriptional regulator gene, orf2: putative MFS transporter gene, orf3: L-phenylserine dehydrogenase gene, orf4: putative dihydroxy acid dehydratase gene, orf5: D-phenylserine dehydrogenase gene, orf6: putative $\mathrm{ABC}$ peptide transporter gene.

biosynthesis [21-23]; however, the operon containing the gene for D-phenylserine dehydrogenase did not contain other genes related to branched-chain amino acids metabolism. orf5 encodes D-phenylserine dehydrogenase, which was previously characterized [16]. orf6 encoded a protein of 520 amino acids that showed high similarity with amino acid sequences of putative $\mathrm{ABC}$ peptide transporters.

orf 3 encodes a protein of 259 amino acids that shares $37 \%$ identity with ketoreductase (RED2) from Streptomyces violaceoruber Tü22 [24] and $28 \%$ identity with 1,3,8trihydroxynaphthalene reductase (3HNR) from Magnaporthe grisea (Figure 4) $[25,26]$. The amino acid sequence of ORF3 also shows high similarity to that of putative short chain dehydrogenases and putative 3-oxoacyl-(acylcarrier protein) reductases and $24 \%$ identity with serine dehydrogenase from Agrobacterium tumefaciens ICR 1600 [27]. A common GXXXGXG sequence, which is characteristic of an $\mathrm{NAD}(\mathrm{P})$-binding site conserved in serine dehydrogenase and its homologs [27], was found in the Nterminal region of ORF3. For these reasons, we assumed that ORF3 has dehydrogenase activity, and considered that 3-hydroxy amino acids were likely to serve as a substrate for the enzyme, so cloning of orf 3 was done.

3.3. Purification of L-Phenylserine Dehydrogenase (ORF3). ORF3 was purified to homogeneity from the recombinant E. coli JM109 cell carrying pSORF3. ORF3 has a calculated molecular mass of $27498.3 \mathrm{Da}$. The purified protein gave a single band with a molecular mass of $27 \mathrm{kDa}$ on SDS-PAGE. The molecular mass of the native protein was determined to be $98 \mathrm{kDa}$ by gel filtration. Because the elution of ORF3 was likely slightly slowed by nonspecific hydrophobic and ionic interactions between ORF3 and the gel filtration resin, the apparent molecular mass of the protein was most likely an underestimate. Therefore, ORF3 probably consists of four identical subunits. A summary of the specific activity and recovery of ORF3 during purification is shown in Table 1.

3.4. Properties of L-Phenylserine Dehydrogenase (ORF3). The molecular characteristics of the enzyme are shown in Tables 2, 3, and 4 . The enzyme was significantly inhibited by $0.05 \mathrm{mM}$ p-chloromercuribenzoate and $0.01 \mathrm{mM}$ $\mathrm{HgCl}_{2}$. However, thiol reagents, such as $\mathrm{N}$-ethylmaleimide and iodoacetamide, the chelating agent EDTA, and bivalent metal cations did not affect the enzyme (Table 2). The enzyme acted in an $\mathrm{NAD}^{+}$-dependent way on $\mathrm{DL}^{-}$ threo- $\beta$-phenylserine but not on $\mathrm{D}$-threo- $\beta$-phenylserine. Because we could not obtain pure $\mathrm{L}$-threo- $\beta$-phenylserine,
TABle 1: Purification of recombinant L-phenylserine dehydrogenase.

\begin{tabular}{lcccc}
\hline Step & $\begin{array}{c}\text { Activity } \\
\text { units }\end{array}$ & $\begin{array}{c}\text { Protein } \\
m g\end{array}$ & $\begin{array}{c}\text { Specific activity } \\
\text { units } / m g\end{array}$ & $\begin{array}{c}\text { Yield } \\
\%\end{array}$ \\
\hline Crude extract & 1400 & 1100 & 1.3 & 100 \\
$\left(\mathrm{NH}_{4}\right)_{2} \mathrm{SO}_{4}$ fractionation & 1800 & 880 & 2.0 & 130 \\
Q-Sepharose FF & 1100 & 180 & 6.1 & 79 \\
Phenyl-Sepharose & 140 & 22 & 6.5 & 10 \\
\hline
\end{tabular}

The enzyme activity was measured with $20 \mathrm{mM}$ DL-threo- $\beta$-phenylserine and $2.5 \mathrm{mM} \mathrm{NAD}^{+}$in $0.2 \mathrm{M}$ glycine-KCl-KOH buffer $(\mathrm{pH} 10.5)$ at $30^{\circ} \mathrm{C}$.

we were unable to perform enzyme assays with L-threo- $\beta$ phenylserine as a substrate. However, the data we obtained indicate that the enzyme showed activity towards only the Lform. The enzyme also acted on DL-erythro- $\beta$-phenylserine and DL-threo-(2-thienyl)serine. Pure L-forms of these compounds are also unavailable, but the enzyme likely acted on only the L-forms of erythro- $\beta$-phenylserine and threo(2-thienyl)serine. Other amino acids tested did not serve as a substrate. The enzyme showed weak activity toward $(S)$-phenylethanol (Table 3). TLC analysis revealed that the enzyme converted $\mathrm{L}-\beta$-phenylserine $\left(R_{f}=0.52\right)$ into 2 aminoacetophenone $\left(R_{f}=0.63\right)$. Therefore, we considered that the enzyme catalyzed the oxidation of the $\beta$-hydroxyl group of $\mathrm{L}-\beta$-phenylserine and that the reaction product, $\mathrm{L}-$ $\alpha$-amino- $\beta$-keto- $\gamma$-phenylpropionate, spontaneously decarboxylated to form 2-aminoacetophenone (Scheme 2). The enzyme preferred $\mathrm{NAD}^{+}$to $\mathrm{NADP}^{+}$as a coenzyme. The enzyme showed maximal activity at $\mathrm{pH} 11.2$ and was stable between $\mathrm{pH} 6.1$ and 11.2 at $30^{\circ} \mathrm{C}$. The enzyme was stable at temperatures lower than $55^{\circ} \mathrm{C}$ for at least 10 minutes and showed the highest activity at $40^{\circ} \mathrm{C}$ (Table 4 ). The apparent $K_{m}$ values for DL-threo- $\beta$-phenylserine and $\mathrm{NAD}^{+}$were 59 and $2.1 \mathrm{mM}$, respectively.

\section{Discussion}

The enzymological properties of D-phenylserine dehydrogenase have already been reported [16], but the nucleotide sequence of the gene encoding D-phenylserine dehydrogenase was determined in this work. The amino acid sequence of D-phenylserine dehydrogenase shares $24 \%$ identity with 3hydroxyisobutyrate dehydrogenase (TTHA0237) from Thermus thermophilus HB8 [28] and 24\% identity with a possible 3-hydroxyisobutyrate dehydrogenase (PA0743) from Pseudomonas aeruginosa $\mathrm{PAO}$. An alignment of the amino acid sequences of D-phenylserine dehydrogenase, TTHA0237, and PA0743 is shown in Figure 3. Many NAD/NADPdependent dehydrogenases contain the Rossmann fold for nucleotide binding; the pyrophosphate group interacts with the GXGXX (G/A) motif found in the Rossmann fold [29]. This characteristic glycine-rich fingerprint motif was highly conserved in the N-termini of D-phenylserine dehydrogenase, TTHA0237, and PA0743. Similarly, alignment of the amino acid sequence of D-phenylserine dehydrogenase with the sequences of 6-phosphogluconate dehydrogenase from Ovis aries [30], Saccharomyces cerevisiae [31], Lactococcus 


\begin{tabular}{|c|c|c|}
\hline D-PSDH & ME SNHP P RVGF CGI GRMGE PMVQR L L AAGHDVT IWNR S A S K L AA L TT AGAHACDT PQA L G & \\
\hline TTHA0237 & ME KVA F I G L GAMGY PMAGHL ARR F P T L VWNR T F E KA L RHQE E F GS E AV P L E R - - V & 53 \\
\hline \multirow[t]{2}{*}{ PA0743 } & MKQ I A F I GLGMGA PMA TNL L KAGY L LNV F DLVQS AVDGLVAAGA S AAR S ARDAV & 5 \\
\hline & $* * * * * *$ & \\
\hline D-PSDH & E RVD I A L L C LGDGHAV EDVVFGEHGL VHAANP P RY LVDHS T L S P A L T R S L AARWT EATGN & 12 \\
\hline TTHA0237 & AEARV I FTCLPTTR - - - EVYEVAEALYPYLREGTYWVDAT SGEP EASRRLAERLREK - GV & 10 \\
\hline \multirow[t]{2}{*}{ PA0743 } & QGADVV I SML P A SQHV EGL Y LDDDG L L AH I A P GT LV L ECS T I A P T S ARK I HAAARER - GL & 11 \\
\hline & * $\quad *$ & \\
\hline D-PSDH & VWI DAPVSGGTGGAEAGT LA IMAGGEADA I DAVT PVLRAF S ARVT RMGDVGAGQTTKLAN & 18 \\
\hline TTHA0237 & TY LDAPVSGGT SGAEAGT L TVMLGGP E EAVERVRP - F LAYAKKVVHVGPVGAGHAVKA IN & 16 \\
\hline \multirow[t]{2}{*}{ PA0743 } & AMLDA PV S GGT AGA AAGT L T FMVGGDA E A L E KAR P L F EAMGRN I FHAGPDGAGQVAKVCN & 17 \\
\hline & $* * * * * * * * * * * * \quad * * * \quad * \quad * \quad * \quad * * * * \quad * \quad *$ & \\
\hline D-PSDH & QA I VATT LAGLAEA F V LAKR S G I DTGAVP S A L F GGWADS V LMQT LWP RM - - - - - - VTP P & 23 \\
\hline TTHА0237 & NA L L AVNLWAAGEGL L A LVKQGVS AEKAL EV I NA S S GR SNATENL I PQR - - - - - - VLTRA & 222 \\
\hline \multirow[t]{2}{*}{ PA0743 } & NQL L AVLMI GT A E AMA LGVANGL E AKV L A E IMR R S S GGNWA L EVYNPWP GVMENAP A S RD & 23 \\
\hline & * & \\
\hline D-PSDH & DHATGTVRVML KDLNA I A E LAET SATVQRV L P EVRR L LQDAADRGMADADL SQ I F L I GEE & 293 \\
\hline TTHA0237 & F P KT F A L GL LVKDLG I AMGV LDGEKA P S P L L R LAR EVY EMAKR E LGPDADHVEA L R L L ER & 28 \\
\hline \multirow[t]{2}{*}{ PA0743 } & Y S GGFMAQLMAKDLGLAQEAAQA S A S S T PMG S LA L S L Y R L L L KQGY AE RD F S VVQK L FDP & 29 \\
\hline & $* * *$ & \\
\hline D-PSDH & E SQAAK & \\
\hline TTHА0237 & WGGVE I R & \\
\hline PA0743 & TQGQGS & \\
\hline
\end{tabular}

(a)



(b)

FIGURE 3: (a) Alignment of the amino acid sequence of D-phenylserine dehydrogenase (D-PSDH) with the sequences of 3-hydroxyisobutyrate dehydrogenase (TTHA0237) from Thermus thermophilus HB8 (PDB ID: 2CVZ) and 3-hydroxyisobutyrate dehydrogenase (PA0743) from Pseudomonas aeruginosa PAO1 (PDB ID: 3CUM). Conserved residues are marked with an asterisk and the key conserved catalytic residue is highlighted with a black background. The GXGXXG sequence fingerprint motif found in the Rossmann fold is boxed. (b) Alignment of the N-terminal amino-acid sequence of D-PSDH with the sequences of 6-phosphogluconate dehydrogenases from Ovis aries (PDB ID: 1PGN), Saccharomyces cerevisiae (PDB ID: 2P4Q), Lactococcus lactis (PDB ID: 2IYO), and Trypanosoma brucei (PDB ID: 1PGJ). Conserved residues are marked by an asterisk. The GX(G/A)XXG sequence fingerprint motif involved in coenzyme binding is boxed. The residues interacting with the $2^{\prime}$-phosphate group of $\mathrm{NADP}^{+}$are highlighted with a black background. Accession numbers for the proteins used are as follows: D-PSDH, AB499092 (GenBank ${ }^{\mathrm{TM}}$ ); TTHA0237, Q5SLQ6 (TrEMBL); PA0743, Q9I5I6 (TrEMBL); and 6-phosphogluconate dehydrogenase from O. aries, P00349 (Swiss-Prot); S. cerevisiae, P38720 (Swiss-Prot); L. lactis, P96789 (Swiss-Prot); T. brucei, P31072 (Swiss-Prot). 


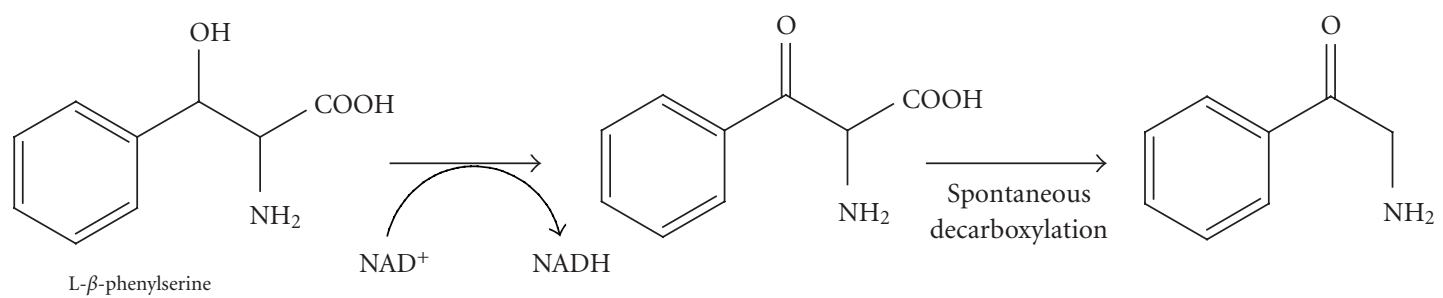

Scheme 2: L-Phenylserine dehydrogenase reaction.

TABLE 2: Effect of various compounds on the activity of L-phenylserine dehydrogenase.

\begin{tabular}{lcc}
\hline Compound & $\begin{array}{c}\text { Concentration } \\
(\mathrm{mM})\end{array}$ & $\begin{array}{c}\text { Relative activity } \\
(\%)\end{array}$ \\
\hline None & - & 100 \\
p-Chloromercuribenzoate & 0.05 & 0 \\
$N$-Ethylmaleimide & 1 & 89 \\
Iodoacetamide & 1 & 91 \\
$\mathrm{EDTA}^{a}$ & 1 & 94 \\
$\mathrm{HgCl}_{2}$ & 0.01 & 21 \\
$\mathrm{CuSO}_{4}$ & 1 & 110 \\
$\mathrm{ZnSO}_{4}$ & 1 & 92 \\
$\mathrm{MnSO}_{4}$ & 1 & 110 \\
$\mathrm{MgSO}_{4}$ & 1 & 100 \\
$\mathrm{BaCl}_{2}$ & 1 & 99 \\
$\mathrm{NiCl}_{2}$ & 1 & 95 \\
$\mathrm{CoCl}_{2}$ & 1 & 94 \\
$\mathrm{CaCl}_{2}$ & 1 & 93 \\
$\mathrm{KCl}$ & 187 & 87 \\
\hline
\end{tabular}

L-Phenylserine dehydrogenase activity was determined in reaction mixtures containing the indicated additive, $20 \mathrm{mM}$ DL-threo- $\beta$-phenylserine and $2.5 \mathrm{mM} \mathrm{NAD}^{+}$in $0.2 \mathrm{M}$ glycine-KCl-KOH buffer $(\mathrm{pH} 10.5)$ at $30^{\circ} \mathrm{C}$.

${ }^{a}$ Ethylenediaminetetraacetic acid.

lactis [32], and Trypanosoma brucei [33] showed that the GX(G/A)XXG motif and residues interacting with $2^{\prime}$ phosphate group of $\mathrm{NADP}^{+}(\mathrm{Gln} 36$ and Arg37) were highly conserved among these enzymes. D-Phenylserine dehydrogenase and these 6-phosphogluconate dehydrogenases prefer $\mathrm{NADP}^{+}$to $\mathrm{NAD}^{+}$as a coenzyme. Moreover, a catalytic residue, Lys177, was also conserved in D-phenylserine dehydrogenase, TTHA0237, and PA0743.

The molecular characteristics of L-phenylserine dehydrogenase and $\mathrm{D}$-phenylserine dehydrogenase are summarized in Table 4. The amino acid sequences of these enzymes showed no homology to each other and each enzyme belongs to a different protein family. The amino acid sequence of $\mathrm{L}^{-}$ phenylserine dehydrogenase was similar to those of ketoreductase (RED2) from Streptomyces violaceoruber Tü22 [24] and 1,3,8-trihydroxynaphthalene reductase (3HNR) from Magnaporthe grisea $[25,26]$. The amino acid sequences of L-phenylserine dehydrogenase and two homologs belonging to the short chain dehydrogenase/reductase (SDR) family
TABLE 3: Substrate specificity of L-phenylserine dehydrogenase.

\begin{tabular}{lcc}
\hline Compound & $\begin{array}{c}\text { Concentration } \\
(\mathrm{mM})\end{array}$ & $\begin{array}{c}\text { Relative activity } \\
(\%)\end{array}$ \\
\hline DL-threo- $\beta$-phenylserine & 20 & 100 \\
D-threo- $\beta$-phenylserine & 10 & 0 \\
DL-erythro- $\beta$-phenylserine & 20 & 840 \\
DL-threo-(2-thienyl)serine & 20 & 530 \\
(S)-phenylethanol & 10 & 6.9 \\
DL-hydroxynorvaline & 20 & 0 \\
L-threonine & 10 & 0 \\
D-threonine & 10 & 0 \\
L-allo-threonine & 10 & 0 \\
D-allo-threonine & 10 & 0 \\
L-serine & 10 & 0 \\
D-serine & 10 & 0 \\
L-phenylalanine & 10 & 0 \\
D-phenylalanine & 10 & 0
\end{tabular}

L-Phenylserine dehydrogenase activity was determined in reaction mixtures containing 10 or $20 \mathrm{mM}$ substrate, as indicated, and $1.0 \mathrm{mM} \mathrm{NAD}^{+}$in $0.2 \mathrm{M}$ glycine-KCl-KOH buffer $\left(\mathrm{pH} \mathrm{10.5)}\right.$ at $30^{\circ} \mathrm{C}$.

aligned well (Figure 4). Members of the SDR family contain a similar structural fold, which shows a common nucleotidebinding site characterized by a GXXXGXG fingerprint motif [25]. Moreover, Arg or Asp residues located 18-20 residues downstream from the motif are responsible for nucleotide specificity $[25,34]$. The characteristic glycinerich fingerprint motif was conserved in the N-terminus of L-phenylserine dehydrogenase. Acidic residues, Asp36 or Asp37, which are 20 and 21 residues downstream, respectively, from the motif probably recognize the $2^{\prime}$-hydroxy group of $\mathrm{NAD}^{+}$. Our kinetic analysis also indicated that $\mathrm{L}^{-}$ phenylserine dehydrogenase prefers $\mathrm{NAD}^{+}$to $\mathrm{NADP}^{+}$as the coenzyme. An X-ray structure of $3 \mathrm{HNR}$ complexed with NADPH and tricyclazole revealed that Ser164, Tyr178, and Lys 182 compose the catalytic triad [25]. These residues were highly conserved in L-phenylserine dehydrogenase, RED2, and 3HNR (corresponding to Ser148, Tyr162, and Lys166 in L-phenylserine dehydrogenase) (Figure 4).

Although threonine [14, 35-37], serine [38, 39], and phenylalanine [40] serve as substrates for many enzymes acting on phenylserine, these amino acids were not accepted as substrates by L-phenylserine dehydrogenase. Among the 
TABLE 4: Comparison of L-phenylserine dehydrogenase (L-PSDH) with D-phenylserine dehydrogenase (D-PSDH).

\begin{tabular}{|c|c|c|}
\hline & L-PSDH & D-PSDH \\
\hline Protein & short-chain & $\beta$-hydroxy acid \\
\hline family & dehydrogenase & dehydrogenase \\
\hline Molecular mass & $98 \mathrm{kDa}$ & $70 \mathrm{kDa}$ \\
\hline Molecular mass of subunit & $27 \mathrm{kDa}$ & $31 \mathrm{kDa}$ \\
\hline Number of subunits & 4 & 2 \\
\hline Coenzyme specificity & $\mathrm{NAD}^{+}$ & $\mathrm{NADP}^{+}$ \\
\hline Optimum pH & pH 11.2 & pH 10.4 \\
\hline pH Stability & pH 6.1-11.2 & pH 6.7-9.1 \\
\hline Thermostability & $55^{\circ} \mathrm{C}$ or below & $50^{\circ} \mathrm{C}$ or below \\
\hline Substrate specificity & L-form & L-form \\
\hline
\end{tabular}
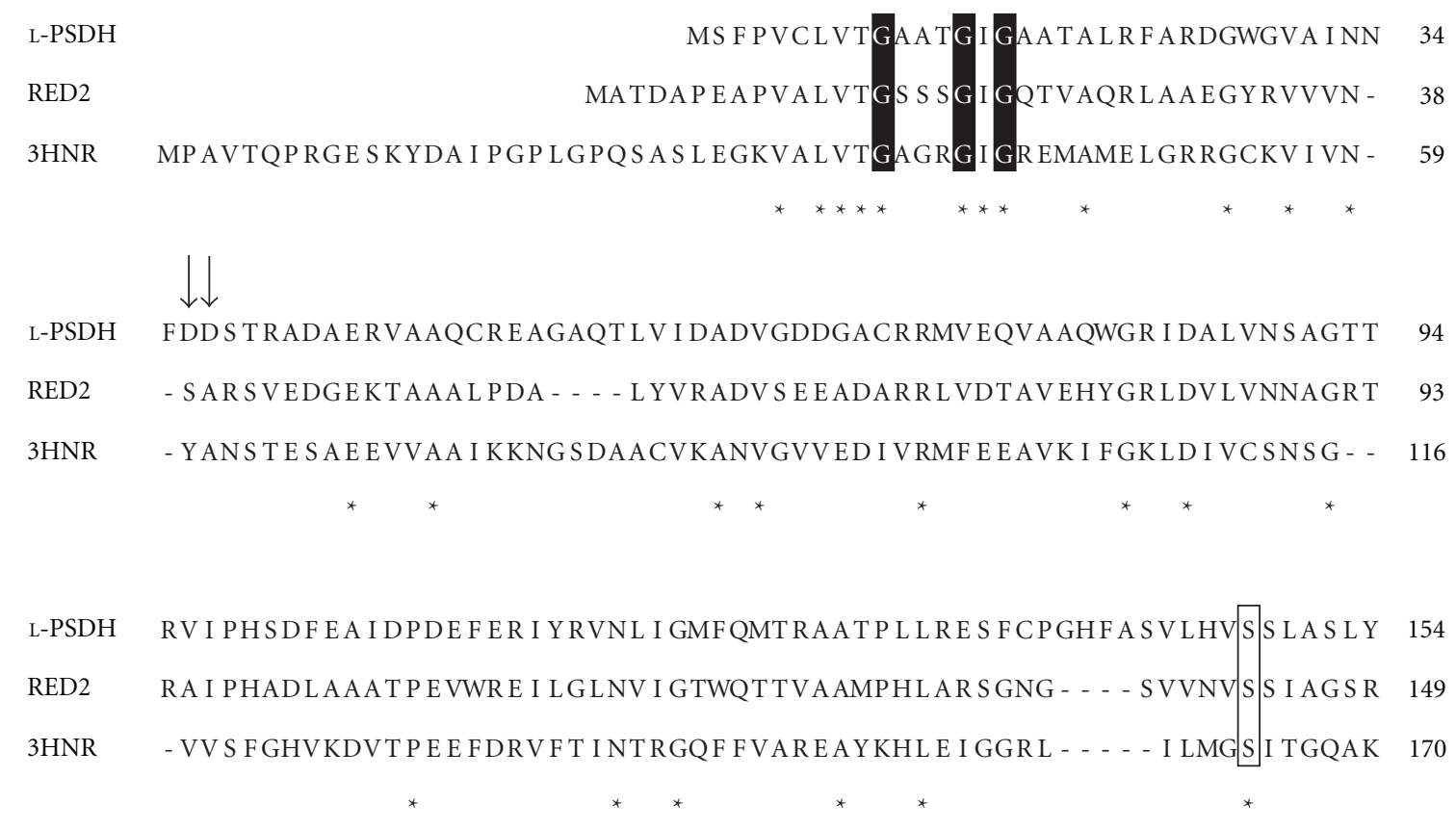

FIgURE 4: Alignment of the amino acid sequence of L-phenylserine dehydrogenase (L-PSDH) with the sequences of RED2 (ketoreductase) from Streptomyces violaceoruber Tü22 and 1,3,8-trihydroxynaphthalene reductase (3HNR) from Magnaporthe grisea. Conserved residues are marked by an asterisk. Residues forming the catalytic triad are boxed and the glycine-rich fingerprint motif is indicated with a black background. The residues Asp36 and Asp37 are shown by arrows. Accession numbers for the proteins used are as follows: L-PSDH, AB499092 (GenBank $\left.{ }^{\mathrm{TM}}\right)$; RED2, Q65YY6 (TrEMBL); 3HNR, Q12634 (Swiss-Prot). 
amino acids tested, L-phenylserine and L-threo-(2-thienyl)serine were good substrates for L-phenylserine dehydrogenase. The genes encoding L-phenylserine dehydrogenase (ORF3) and D-phenylserine dehydrogenase (ORF5) were located within a single operon, and the reaction product of both enzymes is 2-aminoacetophenone. Moreover, Dphenylserine dehydrogenase is induced by addition of DLthreo- $\beta$-phenylserine to a culture medium as a sole source of carbon and nitrogen [16]. Therefore, we consider that D-phenylserine dehydrogenase acts physiologically on $\mathrm{D}$ threo- $\beta$-phenylserine. For these reasons, we assume that the physiological function of L-phenylserine dehydrogenase is an $\mathrm{NAD}^{+}$-dependent conversion of L-phenylserine into 2aminoacetophenone and carbon dioxide.

\section{Acknowledgment}

The first and the second authors contributed equally to this work.

\section{References}

[1] R. B. Herbert and B. Wilkinson, "Preparation of (2R, 3S)- $\beta$ hydroxy- $\alpha$-amino acids by use of a novel Streptomyces aldolase as a resolving agent for racemic material," Canadian Journal of Chemistry, vol. 72, pp. 114-117, 1994.

[2] R. B. Herbert, B. Wilkinson, G. J. Ellames, and E. K. Kunec, "Stereospecific lysis of a range of $\beta$-hydroxy- $\alpha$-amino acids catalysed by a novel aldolase from Streptomyces amakusaensis," Journal of the Chemical Society, Chemical Communications, no. 2, pp. 205-206, 1993.

[3] S. D. Jolad, J. J. Hoffmann, S. J. Torrance, et al., "Bouvardin and deoxybouvardin, antitumor cyclic hexapeptides from Bouvardia ternifolia (Rubiaceae)," Journal of the American Chemical Society, vol. 99, no. 24, pp. 8040-8044, 1977.

[4] T. Kimura, V. P. Vassilev, G.-J. Shen, and C.-H. Wong, "Enzymatic synthesis of $\beta$-hydroxy- $\alpha$-amino acids based on recombinant $\mathrm{D}^{-}$and $\mathrm{L}$-threonine aldolases," Journal of the American Chemical Society, vol. 119, no. 49, pp. 11734-11742, 1997.

[5] J. Q. Liu, M. Odani, T. Dairi, N. Itoh, S. Shimizu, and H. Yamada, "A new route to L-threo-3-[4-(methylthio)phenylserine], a key intermediate for the synthesis of antibiotics: recombinant low-specificity D-threonine aldolasecatalyzed stereospecific resolution," Applied Microbiology and Biotechnology, vol. 51, no. 5, pp. 586-591, 1999.

[6] J. Q. Liu, M. Odani, T. Yasuoka, et al., "Gene cloning and overproduction of low-specificity D-threonine aldolase from Alcaligenes xylosoxidans and its application for production of a key intermediate for parkinsonism drug," Applied Microbiology and Biotechnology, vol. 54, no. 1, pp. 44-51, 2000.

[7] K. Shibata, K. Shingu, V. P. Vassilev, et al., "Kinetic and thermodynamic control of L-threonine aldolase catalyzed reaction and its application to the synthesis of mycestericin D," Tetrahedron Letters, vol. 37, no. 16, pp. 2791-2794, 1996.

[8] V. P. Vassilev, T. Uchiyama, T. Kajimoto, and C.-H. Wong, "Lthreonine aldolase in organic synthesis: preparation of novel $\beta$-hydroxy- $\alpha$-amino acids," Tetrahedron Letters, vol. 36, no. 23, pp. 4081-4084, 1995.

[9] V. P. Vassilev, T. Uchiyama, T. Kajimoto, and C.-H. Wong, "An efficient chemo-enzymatic synthesis of $\alpha$-amino- $\beta$-hydroxy$\gamma$-butyrolactone," Tetrahedron Letters, vol. 36, no. 28, pp. 5063-5064, 1995.
[10] W. Maruyama, M. Naoi, and H. Narabayashi, "The metabolism of L-DOPA and L-threo-3,4-dihydroxyphenylserine and their effects on monoamines in the human brain: analysis of the intraventricular fluid from parkinsonian patients," Journal of the Neurological Sciences, vol. 139, no. 1, pp. 141-148, 1996.

[11] R. J. Ulevitch and R. G. Kallen, "Purification and characterization of pyridoxal 5 '-phosphate dependent serine hydroxymethylase from lamb liver and its action upon $\beta$ phenylserines," Biochemistry, vol. 16, no. 24, pp. 5342-5350, 1977.

[12] J. Kikuchi, T. Takashima, H. Nakao, et al., "Stereoselective synthesis of $\beta$-phenylserine from glycine and benzaldehyde as mediated by catalytic bilayer membranes, artificial Vitamin $\mathrm{B}_{6}$-dependent enzymes," Chemistry Letters, vol. 22, no. 3, pp. 553-556, 1993.

[13] J. Q. Lui, S. Ito, T. Dairi, N. Itoh, S. Shimizu, and H. Yamada, "Low-specificity L-threonine aldolase of Pseudomonas sp. NCIMB 10558: purification, characterization and its application to $\beta$-hydroxy- $\alpha$-amino acid synthesis," Applied Microbiology and Biotechnology, vol. 49, no. 6, pp. 702-708, 1998.

[14] H. Misono, H. Maeda, K. Tuda, S. Ueshima, N. Miyazaki, and S. Nagata, "Characterization of an inducible phenylserine aldolase from Pseudomonas putida 24-1," Applied and Environmental Microbiology, vol. 71, no. 8, pp. 4602-4609, 2005.

[15] H. Okuda, S. Nagata, and H. Misono, "Cloning, sequencing, and overexpression in Escherichia coli of a phenylserine dehydratase gene from Ralstonia pickettii PS22," Bioscience, Biotechnology and Biochemistry, vol. 66, no. 12, pp. 2755-2758, 2002.

[16] K. Packdibamrung, H. Misono, M. Harada, S. Nagata, and S. Nagasaki, "An inducible $\mathrm{NADP}^{+}$-dependent D-phenylserine dehydrogenase from Pseudomonas syringae NK-15: purification and biochemical characterization," Journal of Biochemistry, vol. 114, no. 6, pp. 930-935, 1993.

[17] H. Saito and K.-I. Miura, "Preparation of transforming deoxyribonucleic acid by phenol treatment," Biochimica et Biophysica Acta, vol. 72, pp. 619-629, 1963.

[18] H. Yamamoto, A. Matsuyama, and Y. Kobayashi, "Synthesis of ethyl (S)-4-chloro-3-hydroxybutanoate using fabGhomologues," Applied Microbiology and Biotechnology, vol. 61, no. 2, pp. 133-139, 2003.

[19] S. F. Altschul, W. Gish, W. Miller, E. W. Myers, and D. J. Lipman, "Basic local alignment search tool," Journal of Molecular Biology, vol. 215, no. 3, pp. 403-410, 1990.

[20] J. D. Thompson, D. G. Higgins, and T. J. Gibson, "CLUSTAL $\mathrm{W}$ : improving the sensitivity of progressive multiple sequence alignment through sequence weighting, position-specific gap penalties and weight matrix choice," Nucleic Acids Research, vol. 22, no. 22, pp. 4673-4680, 1994.

[21] J. A. Wechsler and E. A. Adelberg, "Antipolarity in the ilv operon of Escherichia coli K-12," Journal of Bacteriology, vol. 98, no. 3, pp. 1179-1194, 1969.

[22] D. L. Blazey, R. Kim, and R. O. Burns, "Molecular cloning and expression of the ilvGEDAY genes from Salmonella typhimurium," Journal of Bacteriology, vol. 147, no. 2, pp. 452462, 1981.

[23] U. Mäder, S. Hennig, M. Hecker, and G. Homuth, "Transcriptional organization and posttranscriptional regulation of the Bacillus subtilis branched-chain amino acid biosynthesis genes," Journal of Bacteriology, vol. 186, no. 8, pp. 2240-2252, 2004. 
[24] T. Taguchi, K. Kunieda, M. Takeda-Shitaka, et al., "Remarkably different structures and reaction mechanisms of ketoreductases for the opposite stereochemical control in the biosynthesis of BIQ antibiotics," Bioorganic and Medicinal Chemistry, vol. 12, no. 22, pp. 5917-5927, 2004.

[25] A. Andersson, D. Jordan, G. Schneider, and Y. Lindqvist, "Crystal structure of the ternary complex of 1,3,8-trihydroxynaphthalene reductase from Magnaporthe grisea with NADPH and an active-site inhibitor," Structure, vol. 4, no. 10, pp. 11611170, 1996.

[26] D.-I. Liao, G. S. Basarab, A. A. Gatenby, B. Valent, and D. B. Jordan, "Structures of trihydroxynaphthalene reductasefungicide complexes: implications for structure-based design and catalysis," Structure, vol. 9, no. 1, pp. 19-27, 2001.

[27] H. Fujisawa, S. Nagata, E. K. Chowdhury, M. Matsumoto, and H. Misono, "Cloning and sequencing of the serine dehydrogenase gene from Agrobacterium tumefaciens," Bioscience, Biotechnology and Biochemistry, vol. 66, no. 5, pp. 1137-1139, 2002.

[28] N. K. Lokanath, N. Ohshima, K. Takio, et al., "Crystal structure of novel NADP-dependent 3-hydroxyisobutyrate dehydrogenase from Thermus thermophilus HB8," Journal of Molecular Biology, vol. 352, no. 4, pp. 905-917, 2005.

[29] M. G. Rossmann, D. Moras, and K. W. Olsen, "Chemical and biological evolution of a nucleotide binding protein," Nature, vol. 250, no. 5463, pp. 194-199, 1974.

[30] M. J. Adams, G. H. Ellis, S. Gover, C. E. Naylor, and C. Phillips, "Crystallographic study of coenzyme, coenzyme analogue and substrate binding in 6-phosphogluconate dehydrogenase: implications for NADP specificity and the enzyme mechanism," Structure, vol. 2, no. 7, pp. 651-668, 1994.

[31] W. He, Y. Wang, W. Liu, and C.-Z. Zhou, "Crystal structure of Saccharomyces cerevisiae 6-phosphogluconate dehydrogenase Gnd1," BMC Structural Biology, vol. 7, article 38, 2007.

[32] R. Sundaramoorthy, J. Iulek, M. P. Barrett, et al., "Crystal structures of a bacterial B-phosphogluconate dehydrogenase reveal aspects of specificity, mechanism and mode of inhibition by analogues of high-energy reaction intermediates," FEBS Journal, vol. 274, no. 1, pp. 275-286, 2007.

[33] C. Phillips, J. Dohnalek, S. Gover, M. P. Barrett, and M. J. Adams, "A 2.8 A resolution structure of 6-phosphogluconate dehydrogenase from the protozoan parasite Trypanosoma brucei: comparison with the sheep enzyme accounts for differences in activity with coenzyme and substrate analogues," Journal of Molecular Biology, vol. 282, no. 3, pp. 667-681, 1998.

[34] N. Tanaka, T. Nonaka, M. Nakanishi, Y. Deyashiki, A. Hara, and Y. Mitsui, "Crystal structure of the ternary complex of mouse lung carbonyl reductase at $1.8 \AA$ resolution: the structural origin of coenzyme specificity in the short-chain dehydrogenase/reductase family," Structure, vol. 4, no. 1, pp. 33-45, 1996.

[35] H. Misono, I. Kato, K. Packdibamrung, S. Nagata, and S. Nagasaki, "NADP ${ }^{+}$-dependent $\mathrm{D}$-threonine dehydrogenase from Pseudomonas cruciviae IFO 12047," Applied and Environmental Microbiology, vol. 59, no. 9, pp. 2963-2968, 1993.

[36] J.-Q. Liu, S. Ito, T. Dairi, et al., "Gene cloning, nucleotide sequencing, and purification and characterization of the lowspecificity L-threonine aldolase from Pseudomonas sp. strain NCIMB 10558," Applied and Environmental Microbiology, vol. 64, no. 2, pp. 549-554, 1998.

[37] Y. Shimizu, H. Sakuraba, R. Kawakami, S. Goda, Y. Kawarabayasi, and T. Ohshima, "L-Threonine dehydrogenase from the hyperthermophilic archaeon Pyrococcus horikoshii OT3: gene cloning and enzymatic characterization," Extremophiles, vol. 9, no. 4, pp. 317-324, 2005.
[38] V. Schirch, S. Hopkins, E. Villar, and S. Angelaccio, "Serine hydroxymethyltransferase from Escherichia coli: purification and properties," Journal of Bacteriology, vol. 163, no. 1, pp. 17, 1985.

[39] S. Delle Fratte, R. H. White, B. Maras, F. Bossa, and V. Schirch, "Purification and properties of serine hydroxymethyltransferase from Sulfolobus solfataricus," Journal of Bacteriology, vol. 179, no. 23, pp. 7456-7461, 1997.

[40] H. Hayashi, K. Inoue, T. Nagata, S. Kuramitsu, and H. Kagamiyama, "Escherichia coli aromatic amino acid aminotransferase: characterization and comparison with aspartate aminotransferase," Biochemistry, vol. 32, no. 45, pp. 12229 12239, 1993. 



Submit your manuscripts at

http://www.hindawi.com
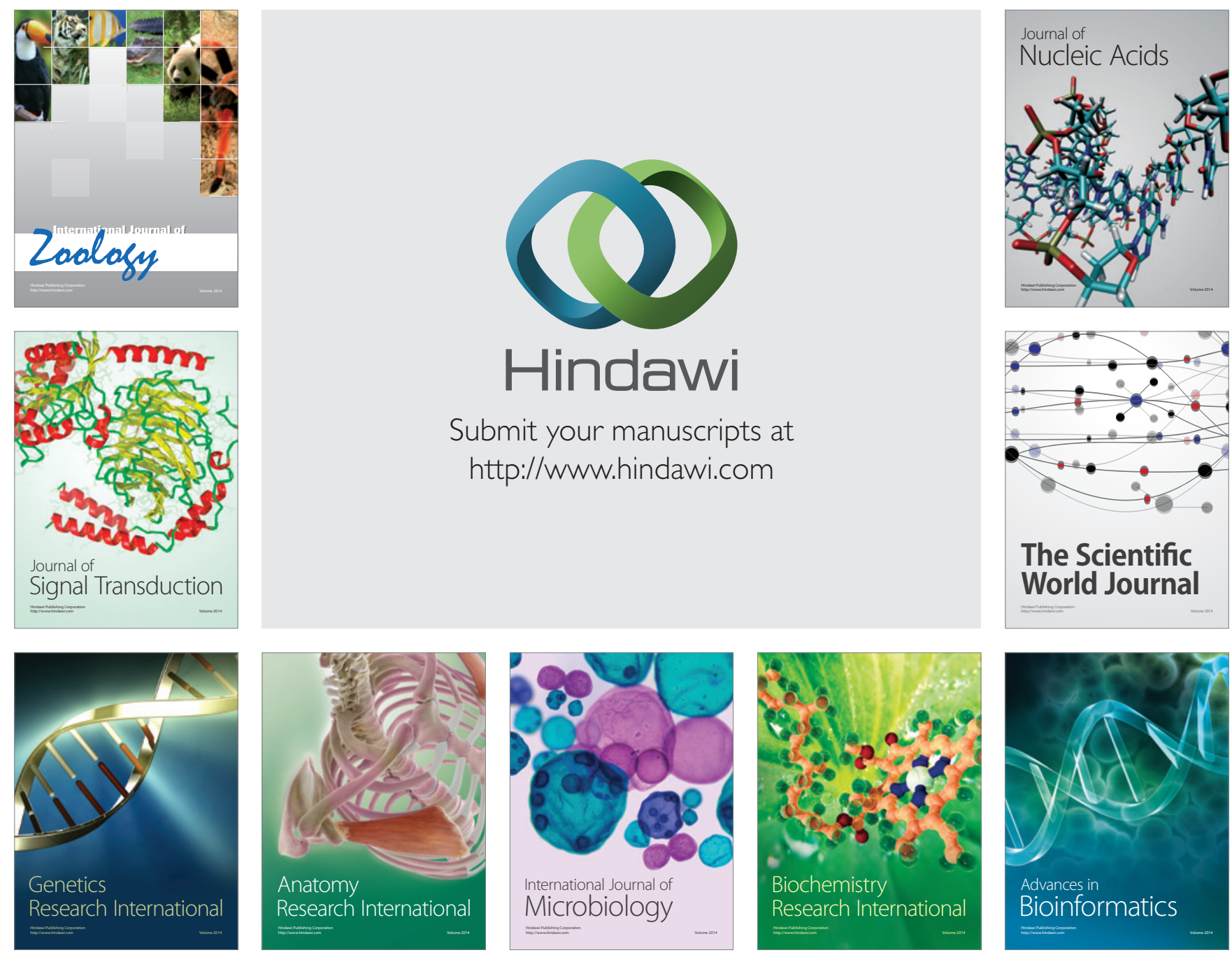

The Scientific World Journal
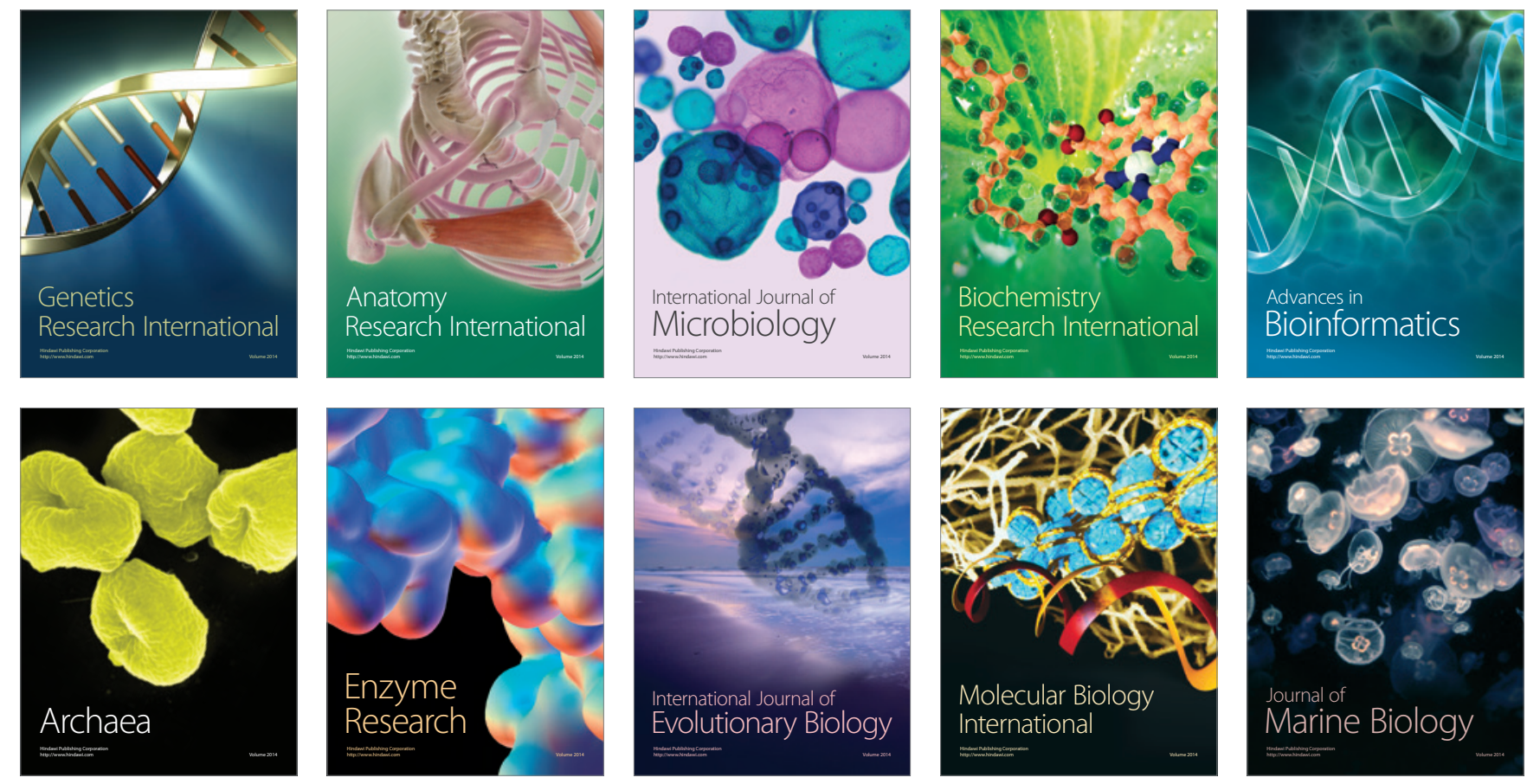